\title{
Hybrid Entrepreneurial Intention: A Comparative Study of Public and Private Sector Employees
}

\author{
Meral Farooq ${ }^{*}$, Nazia Talib² \\ ${ }^{1}$ Institute of Business Administration, University of the Punjab, Lahore, Pakistan \\ *Corresponding author: meralfarooq@gmail.com
}

\begin{abstract}
This paper examined the influence of personality related factors pertinent to perceived behavioral control in the context of theory of planned behavior. Moreover, a comparative analysis was executed to see the variance in the effect of the selected factors with respect to sector of employment in Pakistan. Offline and online survey data was collected from multiple cities across Pakistan using purposive and convenience sampling technique. Regression analysis was run to analyze the data. The findings revealed that the degree of creativity influencing hybrid entrepreneurial intentions varies between public and private sector employees in Pakistan. However, Self-efficacy impacts such intentions approximately in the similar manner in the two sectors of employment. The findings highlight interesting area where public organizations lack as compared to private organizations in terms of creativity of employees. This study extends the body of knowledge on hybrid entrepreneurship in Pakistani settings. This research is among the initial endeavors which undertake a comparative analysis of public and private sector employees towards their hybrid entrepreneurial intentions.
\end{abstract}

\section{ARTICLE INFORMATION}

Received: 5-Mar-2019

Revised: 20-Mar-2019

Accepted: 22-Mar-2019

\section{INTRODUCTION}

An integral feature of decentralized economies is the freedom of individuals to act on their entrepreneurial insights which lead to high level of innovation and creativity in the society. This environment of innovation gives birth to ample opportunities which generate more productive ideas and successful implementation of such ideas promotes economic growth and development in the country. Hence, entrepreneurial insights and intentions invite further investigation in order to fully comprehend the underlying forces. A multitude of interest has been attracted by the phenomenon of entrepreneurship in the recent years and research on entrepreneurship is growing rapidly (Baron \& Markman, 2018).

Entrepreneurship has been defined in different ways ranging from narrow definition such as starting one's own business (Low \& MacMillan, 1988), to broader perspective in the form of a personality characteristics and attitude which indicates attributes such as initiative, taking risk, and self-confidence. Zacharakis, Bygrave, and Shepherd (2000) indicated that entrepreneurship is a strong antecedent of economic growth and approximately between one third and one half of the variance in gross domestic Product (GDP) between different countries is primarily accounted for by entrepreneurial ventures.

Recently a trend has been observed that many individuals take up entrepreneurial activities while simultaneously retaining their primary job. This is termed as hybrid entrepreneurship (Campbell \& De Nardi, 2009; Folta, Delmar, \& Wennberg, 2010). Thorgren, Nordström, and Wincent (2014) concluded that "hybrid" entrepreneurs comprise a significant portion of overall global entrepreneurial activity. An important feature of hybrid entrepreneurship is that it reduces the level of risk and uncertainty connected with initiating a new business (Folta et al., 2010). According to the "Global Entrepreneurship Monitor (GEM)" report of 2003, approximately 80 percent of the fresh entrepreneurs initiate their business without forgoing their wage work (Reynolds et al., 2005). Therefore, the uncertainty in the economic and political environment prevailing in most of the under developed nations seems to provide grounds for growing numbers of Hybrid entrepreneurs.

Much is known about predictors of entrepreneurial intentions in terms of cultural and situational factors (Bruton \& Ahlstrom, 2003; Hofstede, 2001) and some other factors relating to psychological characteristics (Krueger Jr, Reilly, \& Carsrud, 2000; Segal, Borgia, \& Schoenfeld, 2005). But there is scarcity of research that focuses on factors which influence intentions of hybrid entrepreneurs (Indudewi \& Yuanita, 2015; Raffiee \& Feng, 2014).

Since it is of pivotal importance to explore the potential areas possessing entrepreneurial intentions in different sectors of employment. Knowledge of such insights can be instrumental in devising relevant policies which further nurture and promote such intentions resulting in entrepreneurial activity and thereby national growth and development. This study endeavors to investigate and compare the specific impact of two new factors that influence hybrid entrepreneurial intentions of individuals across public and private sector organizations in Pakistan. The factors studied in this paper include Entrepreneurial self-efficacy and Creativity among employees. We begin with identification of two personality related factors from existing literature, lying in the realm of perceived behavioral controls in the context of theory of planned behavior. Then theoretical frame work is developed for these two significant factors since these factors can facilitate or inhibit hybrid entrepreneurial intentions of individuals. 


\section{Theoretical Foundation of the Study}

The theory of planned behavior given by Ajzen (1991) elucidates that the intentions of the individuals predict their behavior, and the three determinants of intention as categorized by him are behavioral attitude of the individuals, their subjective norms and the perceived behavioral control shown by them. Attitude in terms of TPB is how much favorable a person considers any behavior and what outcomes he/she expects from the behavior The Subjective norms means the perceived pressure from the most important people in a person's life i.e. family and friends to perform any particular behavior. These norms are based on social beliefs. The third determinant of TPB is perceived behavioral control which is referred as perceived ease or difficulty to perform any behavior. It is usually based on the personal shortcomings and hurdles by the outside environment (Ajzen, 1991; Gird \& Bagraim, 2008).

The same model of TPB can be applied to hybrid entrepreneurship. Ajzen (1991) is of the view that the intention of the individuals to perform any behavior depends on some motivational factors which determine the willingness of people for trying to perform that behavior. The performance of any behavior depends on the intention and volitional control of the person (i.e. whether a person chooses to perform a behavior or not). Similarly, applying this for hybrid entrepreneurship, it is logically asserted that hybrid entrepreneurial intentions of the individuals are dependent on motivational factors which influence their actions. The entrepreneurial intentions are determined from attitude, subjective norms and perceived behavioral control of the individual and available resources.

Based on above discussion, the researchers suggest in this study that the creativity of a person and his self-efficacy to perform any behavior fall in the category of perceived behavior control. Both of these characteristics facilitate the performance of hybrid entrepreneurial process and ultimately the hybrid entrepreneurial behavior. This argument is based in the logic that if a person perceives himself to be more creative and possess more self-efficacy to perform hybrid entrepreneurship, he will have stronger entrepreneurial intention and that will lead towards better entrepreneurial behavior and performance.

\section{Hybrid Entrepreneurial Intentions}

A lot of previous studies argue that intentions have a very significant and relevant role in decision making of starting a new business/firm(Liñán \& Chen, 2009). So, the studies related to hybrid entrepreneurial intention and behavior are very helpful and beneficial in understanding the entrepreneurship field in general. Intentionality is basically a state of an individual's mind which directs a person's attention, (his/her actions and experiences) to achieve a specific goal or object.. Krueger (1993) is of the view that the commitment of an individual to perform any future behavior is represented by his intention. Similarly, in the case of hybrid entrepreneurship, the hybrid entrepreneurial intentions determine the future target behavior of a person to start a new part-time business alongside his/her full time job.

Therefore, for this study, we can define the hybrid entrepreneurial intentions as a person's commitment and desire to start and run a part time business alongside a full time job(Krueger, 1993). The Hybrid entrepreneurial intentions are based on rationality as well as intuition of individuals and they motivate a person for persistence (Bird \& Jelinek, 1988). The researchers are of the view that the personality of individual and social contexts like economic indicators and variable interact with the intuitions and rationality to form the hybrid entrepreneurial intentions of an individual. All these contexts are basically based on the dynamics that ultimately influence the perceived behavioral control dimension of TPB given by Ajzen (1991). The perceived behavioral control leads towards entrepreneurial intention and then behavior.
The hybrid entrepreneurial intention of Individuals has certain personal and monetary motives behind it. Firstly, this is usually considered as a means of supplementary income. Individuals might want to pursue hybrid entrepreneurship as it provides an attractive source of income as a second job along with the benefits of flexibility of timing for scheduling work. Secondly, it also provides a means to get some non-monetary benefits that are not available in the primary job of individual like exposure, learning etc and lastly, it also gives a chance to individuals to partially experience the self-employment and gain an insight that whether they want to pursue a full time selfemployment and set their own business full time. It avoids the costs related to switching and transition and allows flexibility (Thorgren et al., 2014).

\section{Creativity and Hybrid Entrepreneurial Intentions:}

Creativity is defined as the production of some useful, novel and innovative ideas in any field of life or domain including science, arts, humanities and many such other fields (Amabile, 1996). This is usually categorized as a domain-general characteristic. i.e. if an individual is creative in a particular field of life, there are strong chances that he will be creative in other fields as well and will be finding new and novel ways of doing a task (Silvia, Martin, \& Nusbaum, 2009). This is an inborn trait in all the human beings but only very few people actually use this characteristics and take benefit from it in a positive way (Maslow, 1971). Using creativity successfully at workplace involves much more than merely doing things in a different way (Amabile, 1996); the creative or new idea given by the individual must be actionable, appropriate and useful as well so that you can positively influence the process of how the things are get done at your business and it will ultimately improve the current situation or provide a new way of approaching a specific process. This definition is very relevant for the entrepreneurs as they belong to many diverse fields and they have to solve many problems and find many novel ways of doing their routine business tasks.

Many previous researches have shown creativity is a very important factor than influences entrepreneurial intention of individuals. Olawale, Adeniyi, and Olubela (2010) gave the findings that creativity is one of the important motivators of creating entrepreneurial intentions. Moreover, in another study by Zampetakis and Moustakis (2006), it was found that self-perceptions of creativity by students and the creativity promoting environment in their families can influence their entrepreneurial intentions positively. So, on above basis, we can argue that an important factor that can affect the entrepreneurial intention is creativity. Hence, on the basis of previous studies and in the perspective of comparison between creativity of public and private employees, we hypothesize that:

H1: Creativity has positive significant relationship with Hybrid Entrepreneurial Intention in public sector employees.

H2: Creativity has positive significant relationship with Hybrid Entrepreneurial Intention in private sector employees.

\section{Self-Efficacy and Hybrid Entrepreneurial Intention}

The previous literature has shown that the perceived belief of selfefficacy is a strong determinant of individual's intention and its subsequent implementation(Boyd \& Vozikis, 1994; Douglas \& Fitzsimmons, 2013). More precisely, Self-efficacy is defined as the belief of an individual that he can perform any specific task and obtain the desired results or outcome from it(Bandura, 1977). Wood and Bandura (1989) are of the view that people who are same on their skill level can perform differently from each other based on the level of their self-efficacy and the motivation created by that efficacy to solve the problems. Bandura (1977) argues that the people who are usually high on self-efficacy will start and then remain persistent with any specific task in comparison of those with low self-efficacy who will not be that persistent in their tasks due to their low self-belief. One important characteristic of self-efficacy is that it is always a domain specific judgment of an individual about any novel idea or result related to any specific task (Ford, 1996). It can also be described that an individual 
can have high level of self-efficacy in one field/area while the same individual can be at a low level of self-efficacy at any other area/field related to a different task.

Entrepreneurial self-efficacy is defined as a how much strong a person's self-belief is that that he is capable of performing the different routine tasks involved in entrepreneurship (Boyd \& Vozikis, 1994) According to Chen, Greene, and Crick (1998) the people who possess strong entrepreneurial self-efficacy are more likely to associate the different challenging situations with rewards like psychological fulfillment, community recognition, and economic benefits i.e. profit (Hisrich \& Brush, 1984). Self-efficacy is more concerned with future decisions and choices of individual and it has nothing to do with past actions of an individual. As the more empowered individuals usually feel more self-efficacious, there are strong chances of them to be innovative and inventive in their work and expect success (Spreitzer, 1995). A lot of studies related to the topic of entrepreneurial selfefficacy have remained focused on finding the direct effects of selfefficacy on different entrepreneurial outcomes, including entrepreneurial intentions (Chen et al., 1998); and many other variables as performance of the firm (Forbes, 2005), recognition of opportunity (Ozgen \& Baron, 2007); and intrapreneurial intentions among individuals (Douglas \& Fitzsimmons, 2013).

To sum up, it is argued that the relationship between self-efficacy and hybrid entrepreneurial intention is usually believed to reflect the willingness of a person to perform a behavior, and the perceived behavioral control looks for all the limitations and hurdles that may exist in performing that behavior. Ajzen (1987) and Bandura (1977) gave the view point that the concepts of perceived behavioral control and self-efficacy are interrelated as they both discuss the factors to achieve a specific behavior. In line with this, (Krueger, 1993) gave the viewpoint that the perceived degree of self-efficacy of an individual that he can start and run a business is a string antecedent of entrepreneurial intentions, and in our case hybrid entrepreneurial intention which leads towards actual behavior. So, we have proposed that self-efficacy is an important dependent variable to determine the hybrid entrepreneurial intentions of public and private employees. Hence, we hypothesize that:

H3: Self Efficacy has positive significant relationship with Hybrid Entrepreneurial Intention in public sector employees.

H4: Self Efficacy has positive significant relationship with Hybrid Entrepreneurial Intention in private sector employees.

\section{RESEARCH METHODOLOGOY}

\section{Data collection}

The researchers used purposive and convenient sampling technique for data collection. In this regard, 300 questionnaires were distributed among diversified population of full time employees in public and private sector organizations in Pakistan. 250 usable copies of questionnaires were received and out of these a sample of 164 respondents was taken after screening the responses where respondents never considered to start their own business along their day job. Moreover, researchers also used electronic survey technique for data collection and 42 online surveys were also included in the sample. Therefore, a total sample of 206 respondents was taken for analysis. The respondents belonged to different age groups, gender, income and education level. The data was collected from multiple cities including Lahore, Kasur and Wazirabad and Gujrat. Further, respondents were also screened based on their sector of employment i.e. public or private.

\section{Measures}

The survey questionnaire used already established scales to measures the constructs in the study. Ten item Problem Solving/Creativity Subscale (PSCS) from the Self-Description Questionnaire III (SDQ III) developed by Marsh and O'Neill (1984) was used to measure creativity. The responses were recorded on seven point Likert scale ranging from 1 to 7 (1 means strongly disagree and 7 means strongly agree). In order to make some items comparable with the other items on the creativity scale reverse coding technique was applied.

Entrepreneurial Self Efficacy was measured on a six item scale adopted from EIQ Scale developed by Liñán and Chen (2006) and respondents were asked to mark the level of agreement from 1('Strongly disagree') to 7('Strongly agree'). Entrepreneurial Intention was also measured on a six item scale developed by Francisco Liñán and Yi-Wen Chen (2006) and and respondents were asked to show the level of agreement from 1('Strongly disagree') to 7 ('Strongly agree').

\section{Demographics}

The sample consisted of 107 (52\%) males and 98 (48\%) females. 39 persons (19\%) fall within the age group of $18-25$ years, 106 persons $(52 \%)$ fall within age group of $26-35,46$ persons (22\%) fall within $36-$ 45 years and 14 persons (7\%) fall within age group of 46 years and above. $4.8 \%$ of the sample consisted of employees with intermediate level education. $27.8 \%$ consisted of graduate level education, $61.9 \%$ consisted of employees with post graduate level education and $5.3 \%$ consisted of doctoral level education. $41 \%$ of sample consisted of public sector employees and 59\% consisted of private sector employees.28 employees (13.6\%) had a monthly family income of less than Rs. 25,000, 62 employees (30\%) had monthly income of Rs.

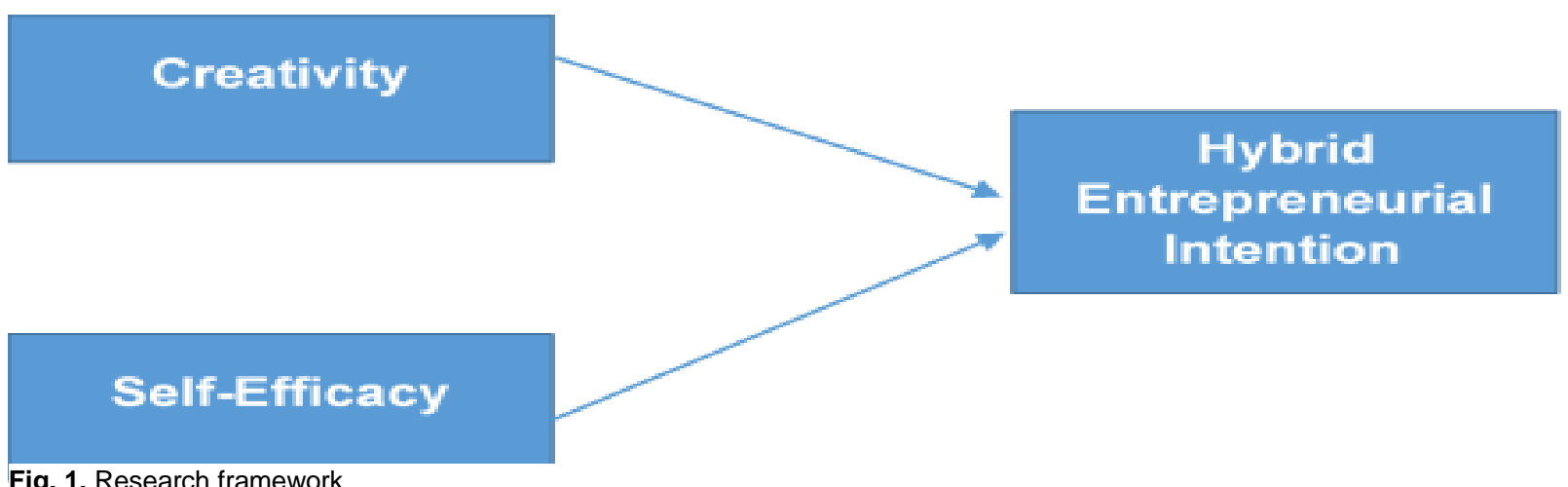

Fig. 1. Research framework 
25,000-50,000 and majority of the sample i.e. 115 employees $(56 \%)$ had monthly income of above Rs. 50,000.

Table 1: Descriptive Statistics

\begin{tabular}{|c|c|c|c|c|c|c|c|c|}
\hline & \multirow{2}{*}{$\begin{array}{l}\text { Minimum } \\
\text { Statistic }\end{array}$} & \multirow{2}{*}{$\begin{array}{c}\text { Maximum } \\
\text { Statistic }\end{array}$} & \multirow{2}{*}{$\begin{array}{c}\text { Mean } \\
\text { Statistic }\end{array}$} & \multirow{2}{*}{$\begin{array}{c}\text { Std. Deviation } \\
\text { Statistic }\end{array}$} & \multicolumn{2}{|c|}{ Skewness } & \multicolumn{2}{|c|}{ Kurtosis } \\
\hline & & & & & Statistic & Std. Error & Statistic & Std. Error \\
\hline Gender & 1 & 2 & 1.48 & .501 & .089 & .170 & -2.012 & .338 \\
\hline Age & 1 & 4 & 2.17 & .814 & .449 & .170 & -.142 & .338 \\
\hline Education & 1 & 4 & 2.68 & .652 & -.631 & .170 & .481 & .338 \\
\hline Sector of Employment & 1 & 2 & 1.59 & .493 & -.370 & .170 & -1.882 & .338 \\
\hline Monthly Family Income & 1 & 3 & 2.42 & .721 & -.841 & .170 & -.619 & .338 \\
\hline Creativity & 3.30 & 6.60 & 4.8146 & .72854 & .129 & .170 & -.645 & .338 \\
\hline Entreprenurial self efficacy & 3.17 & 7.00 & 5.2012 & .82003 & -.205 & .177 & -.630 & .353 \\
\hline Entreprenurial intentions & 3.17 & 7.00 & 5.3179 & .89077 & -.209 & .179 & -.633 & .356 \\
\hline
\end{tabular}

\section{ANALYSIS}

27-item scale was used to check the hybrid entrepreneurial intention of public and private employees through IBM SPSS statistics. To check the normality of data set, multiple tests were run including skewness and kurtosis etc. Q-Q plot, histogram and box plot were also plotted. (See Appendix-II for plots) The results of these tests (after removing the outliers) show that the values of skewness and kurtosis within the range of \pm 0 and \pm 3 . Moreover, the values of skewness and kurtosis divided by their respective standard errors for all three variables fall within the range of \pm 1.15 and \pm 3 respectively, hence on this basis it can be presumed that data is normal and all tests related to normal data can be applied on it. The descriptive depicted in table 1 .

\section{Reliability of Instrument(s)}

Researchers suggest calculating Cronbach Alpha to establish reliability and validity of the instrument. The overall calculated value of Cronbach Alpha for all three variables i.e. Creativity $(\alpha=0.66)$, Entrepreneurial Self-Efficacy $(\alpha=0.88)$ and Entrepreneurial Intention $(\alpha=0.91)$ shows that the reliability of the instrument is established. The following Tables show the reliability of the instrument:

Table 2: Reliability Statistics

\begin{tabular}{lcc} 
& Cronbach's Alpha & N of Items \\
\hline ESE & .884 & 6 \\
EI & .910 & 6 \\
Creativity & .669 & 9
\end{tabular}

$\overline{\mathrm{ESE}}=$ entreprenurial self efficacy, $\mathrm{El}=$ entreprenurial intenstions

\section{Findings}

\section{Comparative Analysis of Public and Private Sector:}

A comparative analysis of public and private sector employees is performed to present the findings, which are as follows:

\section{Public Sector correlation}

Table 3: Correlation results for public sector

\begin{tabular}{|c|c|c|c|}
\hline & Creativity & ESE & El \\
\hline Creativity & 1 & & \\
\hline ESE & 0.002 & 1 & \\
\hline EI & 0.09 & $.380^{* *}$ & 1 \\
\hline
\end{tabular}

The results of Pearson's correlation analysis show that there is no significant relationship between both explanatory variables i.e. Creativity and ESE. Moreover, the Creativity has no significant correlation with EI in Public Sector. However, EI and ESE have significant correlation for Public Sector.

\section{PRIVATE SECTOR CORRELATIONS:}

Table 4: Private sector correlations results

\begin{tabular}{cccc}
\hline & Creativity & ESE & EI \\
\hline Creativity & 1 & & \\
ESE & 0.002 & 1 & 1 \\
EI & 0.09 & $.380^{* *}$ & 1
\end{tabular}

**. Correlation is significant at the 0.01 level (2-tailed).

$\mathrm{ESE}=$ entreprenurial self efficacy, $\mathrm{EI}=$ Entreprenurial intenstions

The results of Pearson's correlation analysis indicate a good linear relationship between Creativity and EI and ESE and EI. Moreover, there is only a weak or insignificant relationships between two explanatory variables i.e. ESE and Creativity so there is no multicollinearity in the data.

\section{MULTIPLE REGRESSION PRIVATE SECTOR}

Regression analysis checks the strength of relationship between dependent and independent variables. The results of regression for checking Hybrid Entrepreneurial Intention of Private Sector Employees are as follows. The adjusted $\mathrm{R}^{2}$ of regression model for private sector is 0.442 with the $\mathrm{R}^{2}=0.452$. This means that the linear regression explains $45.2 \%$ of the variance in the data. So, the model is moderately good fit. Value of $\mathrm{F}$ is 43.8 i.e. it is also greater than 5. So, it is as per acceptable standard for a good model.

Table 5: Regression coefficients public sector

\begin{tabular}{cccccc}
\hline \multicolumn{7}{c}{$\begin{array}{l}\text { Unstandardized } \\
\text { Coefficients }\end{array}$} & $\begin{array}{l}\text { Standardized } \\
\text { Coefficients }\end{array}$ & & \\
\cline { 2 - 4 } Model & $\mathrm{B}$ & $\begin{array}{c}\text { Std. } \\
\text { Error }\end{array}$ & Beta & $\mathrm{t}$ & Sig. \\
\hline (Constant) & .501 & .545 & & .918 & .360 \\
Creativity & .370 & .091 & .301 & 4.083 & .000 \\
ESE & .584 & .080 & .540 & 7.330 & .000 \\
\hline Dependent Variable: Entreprenurial Intentions, ESE = entreprenurial self-efficacy
\end{tabular}

Model extracted through multiple linear regression for private sector employees indicates that the both creativity $(\beta=0.370$, $\mathrm{p}=0.000<0.05)$ and $\operatorname{ESE}(\beta=0.584, \mathrm{p}=0.000<0.05)$ show positive and highly significant direct impact on entrepreneurial intent of private sector employees.

\section{MULTIPLE REGRESSION PUBLIC SECTOR}

To further check the relationship and its strength and to estimate the proposed structural model, we applied multiple linear regression. The results of regression for checking Hybrid Entrepreneurial Intention of Public Sector Employees are as follows:

The adjusted $\mathrm{R}^{2}$ of our model for public sector is .124 with the $\mathrm{R}^{2}$ $=.149$. This means that the linear regression explains only $14.9 \%$ of the variance in the data. 
Table 6: Regression results private sector

\begin{tabular}{|c|c|c|c|c|c|c|}
\hline & \multicolumn{2}{|c|}{$\begin{array}{l}\text { Unstandardized } \\
\text { Coefficients }\end{array}$} & \multirow{2}{*}{$\begin{array}{c}\text { Standardized } \\
\text { Coefficients } \\
\text { Beta }\end{array}$} & \multirow[b]{2}{*}{$\mathrm{T}$} & \multirow[b]{2}{*}{ Sig. } \\
\hline & & B & $\begin{array}{l}\text { Std. } \\
\text { Error }\end{array}$ & & & \\
\hline 1 & $\begin{array}{c}\text { (Constant) } \\
\text { Creativity } \\
\text { ESE }\end{array}$ & $\begin{array}{l}2.446 \\
.078 \\
.469\end{array}$ & $\begin{array}{l}.947 \\
.130 \\
.138\end{array}$ & $\begin{array}{l}.067 \\
.380\end{array}$ & $\begin{array}{c}2.582 \\
.596 \\
3.397\end{array}$ & $\begin{array}{l}.012 \\
.553 \\
.001\end{array}$ \\
\hline
\end{tabular}

Dependent Variable: Entreprenurial Intentions, ESE = entreprenurial self-effiacy

Model extracted through multiple linear regression indicates that the ESE $(\beta=0.469, p=0.001<0.05)$ show positive and highly significant direct impact on entrepreneurial intent of public sector employees. However, creativity $(\beta=0.078, \quad \mathrm{p}=0.553>0.05)$ does not shows significant impact on EI.

\section{DISCUSSION}

The current comparative study was conducted to check hybrid entrepreneurial intentions among public and private sector employees of Pakistan on the basis of their creativity and entrepreneurial selfefficacy. The results of multiple regression analysis revealed that the Creativity and Self Efficacy among Private Sector Employees (H2 and H4) was found to have significant positive impact on Hybrid Entrepreneurial Intention of these employees. Moreover, the Self Efficacy among public sector employees (H3) was found to have significant positive impact on Hybrid Entrepreneurial intention of these employees. However, creativity among public sector employees (H1) did not found to significantly influence the hybrid entrepreneurial intention of them. Thus, hypotheses 2,3 and 4 of this study were supported; while hypotheses 1 was rejected. The results of this study are in line with study of Phipps (2012) who found a positive significant relationship between creativity and entrepreneurial intention. The results are also in line with study by (Van Gelderen et al., 2008), who found a significant positive relationship between self-efficacy and entrepreneurial intention.

\section{CONCLUSION}

The present paper contributes to research stream related to hybrid entrepreneurship in terms of comparative analysis of sector of employment. The variation in entrepreneurial intentions for public and private organizations can be associated with significant differences in the organizational culture of the two sectors. Private organizations are characterized by their participative style of management and decision making, inclusion of all stake holders, acknowledgment of good work, team spirit and conductive work environment which are needed for promotion of creativity and self-efficacy and apparent lack of such factors in public sector organizations could be the probable reason for a lower level of creativity among government employees. Hence, we can say that the employees from private organizations are more creative and possess more self-efficacy and have more intention towards starting a part time business alongside a full time job i.e. they are more inclined towards hybrid entrepreneurship. While the employees belonging to public sector organizations possess self-efficacy but they are not much creative (as evident from the results of this study), hence they show less intention towards hybrid entrepreneurship.

\section{Research Implications}

The present study provides valuable information to policy makers regarding hybrid entrepreneurs. The findings suggest that creativity and self-efficacy are the two factors that motive people towards hybrid entrepreneurship with a varying influence across public and private sector. Therefore, government organizations need to identify the lacking areas which is creativity and try to cover the gap. This would be beneficial not only for organization but also in the broader perspective it will contribute toward national growth with the increased entrepreneurial ventures along wage work. Moreover, private sector organizations can count on the employee creativity and self-efficacy inventory to achieve organizational goals. Further, both public and private sector organizations can device personnel development programs to instigate these to factors among employees. Universities can offer more focused programs in order build and promote stronger entrepreneurial mind set among students. This research contributes to existing literature on hybrid entrepreneurship, by way of comparative analysis of public and private sector employees in Pakistani context.

\section{LIMITATIONS AND FUTURE DIRECTIONS}

The present study considered only two factors to examine their influence on Hybrid Entrepreneurial Intentions. Future researches can be conducted with focus on other less studied factors that influence such intentions. More specific studies can be useful for future policies regarding promotion of entrepreneurship in Pakistan e.g. heath sector, banking sector, educations sector employees can be considered.

\section{REFERENCES}

Ajzen, I. (1991). The theory of planned behavior. Organizational behavior and human decision processes, 50(2), 179-211.

Amabile, T. M. (1996). Creativity in context: Update to the social psychology of creativity: Hachette UK.

Bandura, A. (1977). Self-efficacy: toward a unifying theory of behavioral change. Psychological review, 84(2), 191-215. doi:10.1037//0033295X.84.2.191

Baron, R. A., \& Markman, G. D. (2018). Toward a process view of entrepreneurship: The changing impact of individual-level variables across phases of new firm development. In Current topics in management (pp. 45-63): Routledge.

Bird, B., \& Jelinek, M. (1988). The operation of entrepreneurial intentions. Entrepreneurship theory and practice, 13(2), 21-29.

Boyd, N. G., \& Vozikis, G. S. (1994). The influence of self-efficacy on the development of entrepreneurial intentions and actions. Entrepreneurship theory and practice, 18(4), 63-77.

Bruton, G. D., \& Ahlstrom, D. (2003). An institutional view of China's venture capital industry: Explaining the differences between China and the West. Journal of business venturing, 18(2), 233-259.

Campbell, J. R., \& De Nardi, M. (2009). A conversation with 590 nascent entrepreneurs. Annals of Finance, 5(3-4), 313-340.

Chen, C. C., Greene, P. G., \& Crick, A. (1998). Does entrepreneurial selfefficacy distinguish entrepreneurs from managers? Journal of Business Venturing, 13(4), 295-316.

Douglas, E. J., \& Fitzsimmons, J. R. (2013). Intrapreneurial intentions versus entrepreneurial intentions: distinct constructs with different antecedents. Small business economics, 41(1), 115-132.

Folta, T. B., Delmar, F., \& Wennberg, K. (2010). Hybrid entrepreneurship. Management Science, 56(2), 253-269.

Forbes, D. P. (2005). Are some entrepreneurs more overconfident than others? Journal of business venturing, 20(5), 623-640.

Ford, C. M. (1996). A theory of individual creative action in multiple social domains. Academy of management Review, 21(4), 1112-1142.

Gird, A., \& Bagraim, J. J. (2008). The theory of planned behaviour as predictor of entrepreneurial intent amongst final-year university students. South African Journal of Psychology, 38(4), 711-724.

Hisrich, R., \& Brush, C. (1984). The woman entrepreneur: Management skills and business problems.

Hofstede, G. (2001). Culture's consequences: Comparing values, behaviors, institutions and organizations across nations: Sage publications.

Indudewi, R., \& Yuanita, F. (2015). Success factors of hybrid entrepreneur: Case study of Universitas Ciputra academician.

Krueger Jr, N. F., Reilly, M. D., \& Carsrud, A. L. (2000). Competing models of entrepreneurial intentions. Journal of business venturing, 15(5-6), 411-432.

Krueger, N. (1993). The impact of prior entrepreneurial exposure on perceptions of new venture feasibility and desirability. Entrepreneurship theory and practice, $18(1), 5-21$

Liñán, F., \& Chen, Y.-W. (2006). Testing the entrepreneurial intention model on a two-country sample.

Liñán, F., \& Chen, Y. W. (2009). Development and cross-cultural application of a specific instrument to measure entrepreneurial intentions. Entrepreneurship theory and practice, 33(3), 593-617.

Low, M. B., \& MacMillan, I. C. (1988). Entrepreneurship: Past research and future challenges. Journal of management, 14(2), 139-161. 
Marsh, H. W., \& O'Neill, R. (1984). Self description questionnaire III: the construct validity of multidimensional self-concept ratings by late adolescents. Journal of Educational Measurement, 21(2), 153-174.

Maslow, A. H. (1971). Self-actualization: Big Sur Recordings.

Olawale, S. G., Adeniyi, E. O., \& Olubela, O. I. (2010). Creativity fostering behaviour as an index of productivity and capacity building among lecturers in selected universities in Ogun and Oyo States. Educational Research and Reviews, 5(5), 257-262.

Ozgen, E., \& Baron, R. A. (2007). Social sources of information in opportunity recognition: Effects of mentors, industry networks, and professional forums. Journal of business venturing, 22(2), 174-192.

Phipps, S. T. (2012). Contributors to an enterprising gender: examining the influence of creativity on entrepreneurial intentions and the moderating role of political skill controlling for gender. Academy of Entrepreneurship Journal, 18(1).

Raffiee, J., \& Feng, J. (2014). Should I quit my day job?: A hybrid path to entrepreneurship. Academy of Management Journal, 57(4), 936-963.

Reynolds, P., Bosma, N., Autio, E., Hunt, S., De Bono, N., Servais, I., . . Chin, N. (2005). Global entrepreneurship monitor: Data collection design and implementation 1998-2003. Small business economics, 24(3), 205-231.

Segal, G., Borgia, D., \& Schoenfeld, J. (2005). The motivation to become an entrepreneur. International journal of Entrepreneurial Behavior \& research, 11(1), 42-57.

Silvia, P. J., Martin, C., \& Nusbaum, E. C. (2009). A snapshot of creativity: Evaluating a quick and simple method for assessing divergent thinking. Thinking Skills and Creativity, 4(2), 79-85.

Spreitzer, G. M. (1995). Psychological empowerment in the workplace: Dimensions, measurement, and validation. Academy of Management Journal, 38(5), 1442-1465.

Thorgren, S., Nordström, C., \& Wincent, J. (2014). Hybrid entrepreneurship: the importance of passion. Baltic Journal of Management, 9(3), 314329.

Van Gelderen, M., Brand, M., van Praag, M., Bodewes, W., Poutsma, E., \& Van Gils, A. (2008). Explaining entrepreneurial intentions by means of the theory of planned behaviour. Career development international, 13(6), 538-559.

Wood, R., \& Bandura, A. (1989). Social cognitive theory of organizational management. Academy of management Review, 14(3), 361-384.

Zacharakis, A., Bygrave, W. D., \& Shepherd, D. A. (2000). Global entrepreneurship monitor: national entrepreneurship assessment, United States of America: 2000 executive Report: Kauffman Center for Entrepreneurial Leadership at the Ewing Marion Kauffman ....

Zampetakis, L. A., \& Moustakis, V. (2006). Linking creativity with entrepreneurial intentions: A structural approach. The International Entrepreneurship and Management Journal, 2(3), 413-428. 